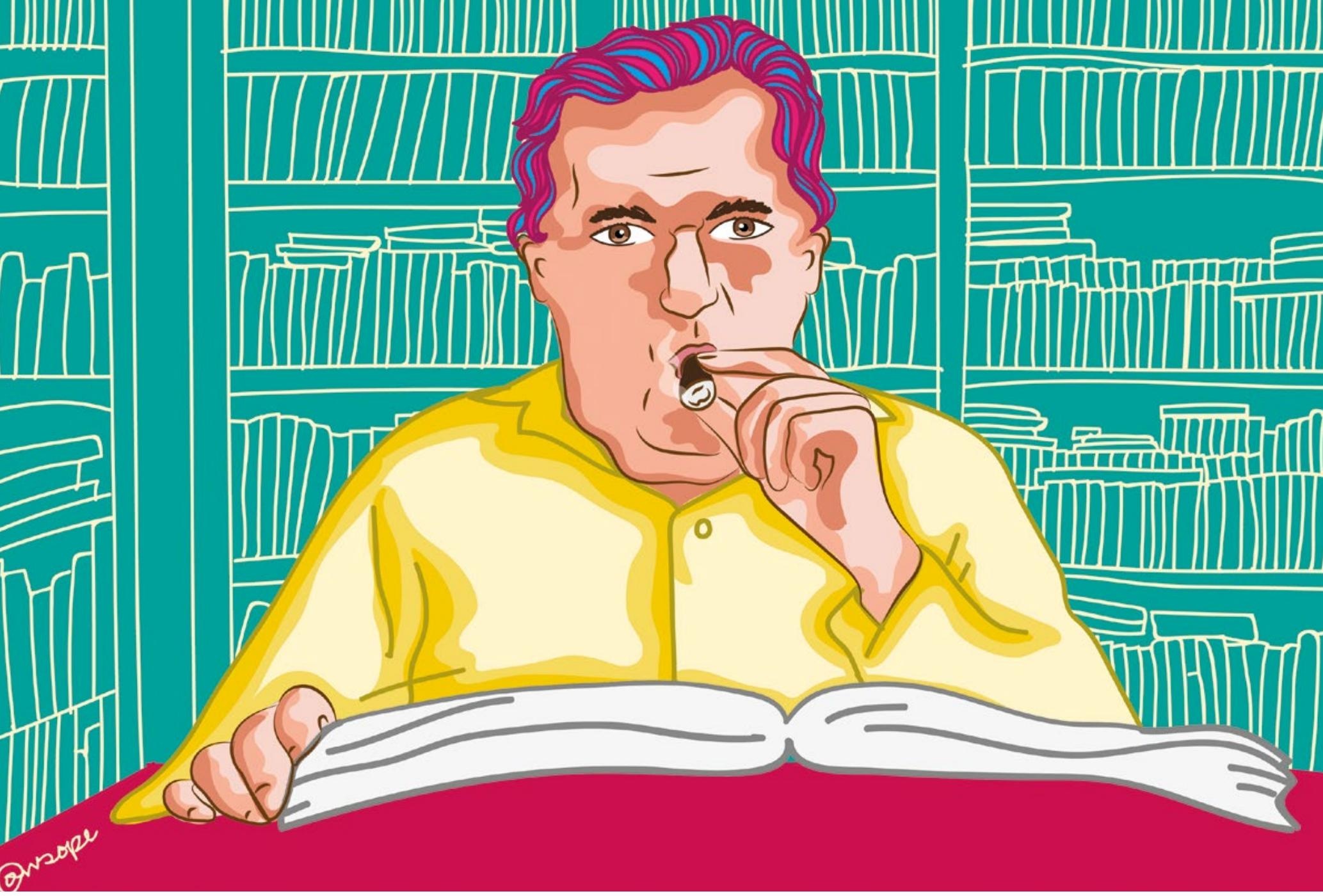

\title{
UNIVERSIDADE POPULAR DO RIO GRANDE DO NORTE
}

Luís da Câmara Cascudo

Instalada a $1 .^{\circ}$ de Maio de 1948 no salão do Instituto Histórico graças a hospitalidade de Nestor Lima. Presidencia de Paulo Pinheiro de Viveiros. Aula inicial sobre a função e técnica das Universidades Populares, programa da qual se inaugurava. Falou Paulo e dois estudantes de Direito, membros na Missão Universitária do Recife que viéra assistir a instalação.

Aulas nas quarta-feiras sob a presidencia de um dos conselheiros, Paulo, Waldermar de Almeida, Luis Veiga ou Sergio Severo de Albuquerque Maranhão.

12-19-26 de Maio, 2 e 9 de junho, curso dado por mim sobre a História da Literatura Norte Rio Grandense, 16 de Junho e 7 de
Julho, Rodrigo [ilegível] falou sobre Agua e a Civilização. Nesta última aula tomou parte no debate o prof. Edgar Altino, diretor da Faculdade de Direito do Recife.

O Padre José Pereira Néto estudou a filosofia de Balmes na noite de 14 de julho. Estudei o Indigena na Cultura Brasileira a 21. O d.r. Januário Cicco evocou a vida heroica do Padre João Maria a 28.

Em Agosto: --- Otto Guerra expoz as doutrinas sociais e as enciclicas de leão XIII, na noite de 4 A. 11 fiz uma aula-curso de Canto gregoriano com o auxilio da Schola Cantorum Salesiana, dirigida pelo Pe. Maria Daorizi no salão da Confederação Católica. Os doidos, 
malucos e normais e organização da assistencia aos psicopatas deram assunto ao dr. João da Costa Machado a 18. No debate tomaram parte o governador do Estado, dr. José Varela e o drietor do SERAS, José Ariston Filho. Na noite de 25 tivemos um estudo sobre a Primeira batalha de Guararapes pelo governador do território de Fernando de Noronha, major Mário Imbiriba.

A 1. ${ }^{\circ}$ de Setembro: --- Aula do dr. Antonio de Mélo Siqueira sobre Malaria e sem combate. A 8, na Escola de Comércio, Paulo Pinheiro de Viveiros fala sobre Comerciários e Legislação do Trabalho. A 15 Paulo evoca reportagens sobre Natal na guerra. A 22 o padre José Sauer dedica um estudo á Biblia.

Outubro: --- a 7, no salão Alberto Maranhão, do teatro Carlos Gomes, Waldemar de Almeida pormenoriza o estudo do canto coral com exemplificações práticas. $\mathrm{O}$ juiz de direito Renato Dantas, na noite de 20, fixa as aplicações da pena no Distrito Penal moderno.

A Universidade realizou vinte e uma aulas publicas, todas terminadas com debates orais, assistdas por auditório simpático, compreensivo e cutusiásta.

Os jornais publicavam, gentilmente, as notas que enviávamos. Documentam a existencia dessa entidade no ano da graça de Nosso Senhor Jesus Cristo de 1948.

Aos indiferentes, anedóticos, analgésicos e agressores, dedico um Padre Nosso e uma Ave Maria.

Este é o relatório que devo ao respeitavel público...

\section{Texto extraído de:}

CASCUDO, Luís da Câmara. Universidade popular do Rio Grande do Norte. A República, 29 mar. 1949. Documento do acervo do Ludovicus - Instituto Câmara Cascudo. 